\title{
BUDGETARY PARTICIPATION AND MANAGERIAL PERFORMANCE IN PUBLIC SECTOR ORGANISATIONS: A STUDY FROM NIGERIA
}

\author{
Babajide OYEWO ${ }^{1}$, Gbadegesin ADYEYE ${ }^{1}$ \\ ${ }^{1}$ Department of Accounting, University of Lagos, Akoka, Lagos, Nigeria \\ Email: meetjidemichael@gmail.com,gadeyeye@unilag.edu.ng
}

\begin{abstract}
This study investigated the impact of budgetary participation on managerial performance in the public sector organisations in Nigeria. A questionnaire was used to obtain the opinion of 174 managers (unit and departmental heads) in five public sector organisations located in Abuja, Nigeria Federal Capital. Results from statistical analysis (descriptive, factor analysis, Kruskal-Wallis tests, correlation and regression) show that there is high level of budgetary participation by managers in public sector organisations in Nigeria. Although budgetary participation was observed to positively and significantly influence managerial functions such as planning, investigating, co-ordinating, supervising, evaluating, and staffing, it exerts the most on planning. The impact of budgetary participation on managerial performance appears to be moderate. Whilst it is desirable for public sector organisations to adopt sophisticated budgeting techniques, the study advocates for employees' motivation and deeper involvement in budget matters as a way out of the traditional budgeting quagmire that public sector organisations are characteristically bedevilled with.
\end{abstract}

Keywords: budgeting; budgetary participation; public sector organisations; managerial performance; traditional budgeting.

JEL Classification: $\mathrm{M}_{4}$

\section{Introduction}

Budgeting has lent itself as one of the classical topics in business or management science disciplines perhaps because it is an activity carried out by different organisations - whatever their age, size, ownership structure, industry sector, international affiliation or establishment motives. As it is a popular practice with private sector organisations to use budgeting for various purposes such as planning, performance monitoring, co-ordinating [Maitland, 2000; Rasmussen, 


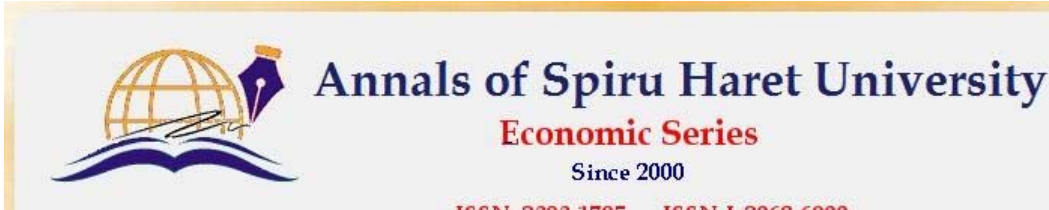

ISSN: 2393-1795 ISSN-L:2068-6900

\section{Issue 1/2018}

2003; Chartered Institute of Management Accountants (CIMA), 2008], the government of nations also uses budgets as a fiscal policy tool [Mihai, 2010; Holynskyy, 2017]. The ubiquitous and multi-faceted nature of budgeting has brought about the behavioural ramifications, because one of the crucial elements in the budgeting system of organisations is the human being. Getting people involved in the budgeting process is critical, and this has caused the emergence of studies investigating the influence of budgetary participation on managerial performance.

Considering that budgeting applies to both private and public sector organisations, some scholars [Bameke, 2008; Mănescu, 2010; Olaopa, 2013] have argued that the subject of budgeting, budgetary participation and managerial performance in the public sector domain is too important to be ignored, because government-owned institutions provide essential services to the citizenry; and that the optimal utilisation of the resources supplied to them to achieve their set-up objectives is paramount. Most public sector organisations receive substantial part of their funding from the government that set them up to provide services to the public. The judicious utilisation of financial resources in such public sector organisations, facilitated by the existence of a sound budgeting system, could translate directly to the efficient utilisation of state resources. Review of literature on budgetary participation (BP) and managerial performance (MP) reveals a leaning towards private sector organisations in comparison to the public sector organisations [see Milani, 1975; Brownell \& McInnes, 1986; Nouri \& Parker, 1998; Chong \& Chong, 2002; Agbejule \& Saarikoski, 2006; Frucot \& White, 2006; Yuen, 2007; Adeyeye, Otusanya \& Uadiale, 2013]. In contributing to the debate on budgetary participation and managerial performance in public sector organisations, Thomson (1967) (cited in Williams, Macintosh \& Moore, 1990), suggested that budgetary behaviour in private sector organisations may be different from public sector settings, thus suggesting limitation in the scope of generalisability of empirical results from budgetary participation and managerial performance in the private sector organisation, hence the need for study of public sector organisations.

The budget preparation process in the Nigerian public sector involves the initiation of a call circular to the various government ministries, departments, agencies and parastatals, who are expected to participate in budgeting activities, such as budget discussions, preparations, defence and implementation [Adams, 2002; Bammeke, 2008]. According to Omolehinwa \& Naiyeju (2015), the budgeting process in the public sector is divided into four broad stages, which are: (a) formulation or preparation stage, (b) approval or enactment stage, (c) implementation stage, (d) monitoring and evaluation stage. At the formulation stage, employees have inputs 48 


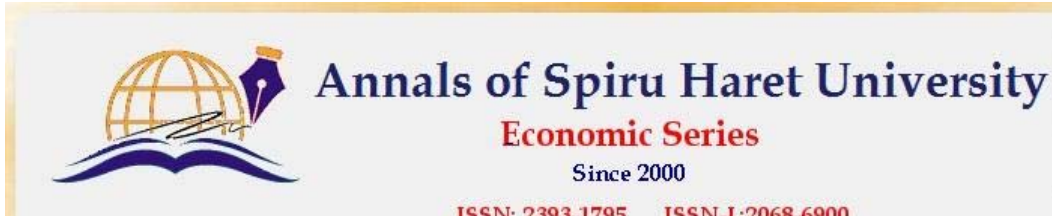

ISSN: 2393-1795 ISSN-I-2068-6900

Issue 1/2018

to the budgets or participate in the budgeting process. Thus, employees in government institutions have crucial bearing on the success or failure of the entire budgeting system, and as a result, the level to which they are involved in the budgetary process is worth unearthing. However, little is known on the extent to which employees participate in budgeting in the Nigerian public sector. Further, as the purposes of budgets are similar with the functions of management, there is the possibility that budgetary participation may affect the discharge of managerial functions (such as planning, organising, controlling, co-ordinating, and decisionmaking, amongst others) - but the influence of budgetary participation on managerial functions in public sector organisations in the Nigerian context is under-researched. Although erstwhile studies on budgeting in private sector and public sector organisations have heretofore investigated the relationship between budgetary participation (BP) and managerial performance (MP) (for example, Stedry, 1960; Bryan \& Locke, 1967; Hofstede, 1968; Milani, 1975; Kenis, 1979; Steers, 1979; Nouri \& Parker, 1998; Wentzel, 2002; Kochi, 2011; Malgwi \& Unegbu, 2012; Noor \& Othman, 2012; Ajibolade \& Akinniyi, 2013; Akinniyi \& Ajibolade, 2013; Owusu, Dwomoh, Collins, Yaa \& Daniel, 2014), there are conflicting views as to the nature of relationship (positive, negative, or neutral) between BP and MP.

This study was undertaken to close some of the observed gaps. The focus of this paper is to appraise the relationship between budgetary participation and managerial performance in the Nigerian public sector. The objectives are to: (i) appraise the level of managers (unit and departmental heads) participation in budgeting; (ii) examine the relationship between budgetary participation and managerial functions; and (iii) investigate the impact of budgetary participation on managerial performance in public sector organisations in Nigeria.

There are five sections (2-6) in the rest of the paper. After the review of literature and development of research hypothesis in section 2, section 3 delves into research methods. Next, results are analysed in section 4 , followed by discussion of findings in section 5 .

The paper is concluded in section 6 .

\section{Literature review and development of hypothesis \\ 2.1. Budgeting techniques}

Budgeting techniques such as incremental or traditional budgeting, Planning, Programming, and Budgeting System (PPBS), Zero Based Budgeting (ZBB) and Activity Based Budgeting, (ABB) have found relevance and use in private sector organisations, and could as well be deployed in public sector institutions. Incremental 


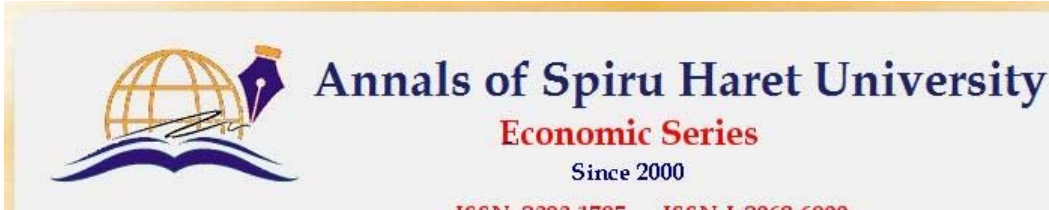

ISSN: 2393-1795 ISSN-L:2068-6900

\section{Issue 1/2018}

budgeting, a technique that adds a specified proportion to the previous year budget figure to allow for inflation and upgrade the previous year figure to the current year estimate, is popular among public sector institution [Adams, 2002]. The use of incremental budgeting has been criticized and identified as one of the fundamental errors in public sector budgeting [Langfield, Thorne \& Hilton, 2006]. Other techniques such as PPBS, ZBB and ABB have been recommended to address this lacuna. The PPBS, $\mathrm{ZBB}$ and $\mathrm{ABB}$ however, require more participation and involvement of employees in the budgeting system. For instance, the PPBS requires the preparation of budgets based on well-justified programmes to be funded by the budgets. The ZBB requires a 'clean slate' fresh justification of budget expenditures by the preparers while the $\mathrm{ABB}$ is based on activity framework and it uses cost driver data in the budget setting and variance feedback processes. The successful deployment of the more advanced, objective, reliable and modern techniques of budgeting such as the PPBS, $\mathrm{ZBB}$ and $\mathrm{ABB}$ in public sector institutions may therefore rely to some extent on the level of participation in budgeting activities, as well as the motivation of employees to achieve set targets.

\subsection{Budgetary participation and managerial performance}

Budgetary participation can be viewed as the opportunity extended to employees or managers to be part of the budgeting process in an organisation [Kennis, 1979; Brownell, 1986; Shields \& Shields, 1998]. Shields \& Shields (1998, p. 49) defined budgetary participation as 'a process in which a manager is involved with, and has influence on, the determination of his or her budget'. The budgeting processes generally involves prioritisation of objectives identified in the planning process; assessment and quantification of total available resources; identification and quantification of the inputs and processes required to fulfil the stated objectives and the associated financial resource required; assignment of proportion(s) of the total resources necessary to acquire/manage inputs to achieve the stated objectives [CIMA Official Terminology, 2005].

Popularly acclaimed managerial roles in management literatures are: planning, organizing, staffing, directing, controlling, co-ordination [O'Reilly, 1989; Yukl, 1994; Vancouver, 1996]. Budgeting serves as a tool for achieving some of these managerial functions, and as such, it is not unexpected to evaluate whether participating in budgeting enhances the discharging of these duties. As to the approaches of budget preparation, budgets may be top-down (imposed), bottom-up (participative) or parallel (negotiated). The bottom-up and parallel approaches allow for employee participation in the budget management process. 


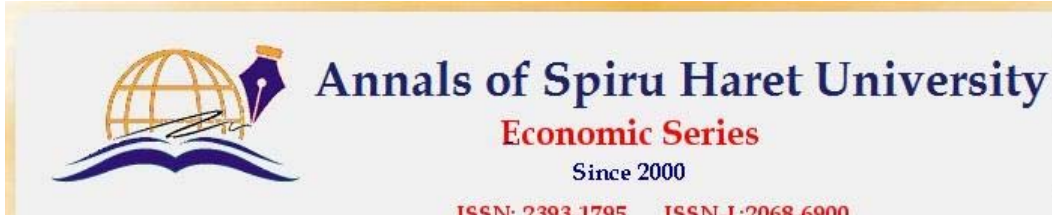

ISSN: 2393-1795 ISSN-I-2068-6900

Issue $1 / 2018$

\subsection{Prior studies on the nexus between budgetary participation and managerial performance}

Empirical researchers have been divided in their submissions as to the nature of relationship between budgetary participation and managerial performance. While some studies have posited a positive relationship between the two variables [e.g., Hofstede, 1968; Nouri \& Parker, 1998; Wentzel, 2002; Adeyeye, Otusanya \& Uadiale, 2013), other studies have asserted a negative relationship (Stedry, 1960; Bryan \& Locke, 1967[. Furthermore, some scholars have argued that there is no difference in the performance of employees that participated in budgeting and those who did not participate [Milani, 1975; Kenis, 1979; Steers, 1979].

Wentzel (2002), upon investigating the influence of goal commitment and perception on fairness by employees in budgetary activities, concluded that participating in budgeting engenders a sense of fairness which in turn increases employees' commitment to achieving budget objectives, leading subsequently to improve budget rating. Some authors have suggested that there are strong linkages between budgetary participation and employee performance [Milani, 1975; Brownell \& McInnes, 1986; Adeyeye, Otusanya \& Uadiale, 2013]. As to the nature of the relationship, the strength of relationships reported by various research outputs have varied from strong positive relationship [Nouri \& Parker, 1998; Yuen, 2007; Yahya et al., 2008], to weak positive relationship [Milani, 1975], and even to a negative relationship [Kenis, 1979]. Whilst contending that no single, definitive and universal relationship exists between budgetary participation and managerial performance amongst the results reported for studies of private sector organisations because of other intervening variables, Nikmah (2012) stated that the study of such relationship for government-owned public service institutions is scanty.

Yuen (2007), in a study of budgetary participation in a Macau governmentowned institution, found that two antecedent factors, the need for achievement and work attitude, positively affect budgetary participation. Owusu et al. (2014) assessed the relationship between budgetary participation and employee performance in a Ghanaian public university. Although the results of the study establish some level of relationship between budgetary participation and employee performance, the strength of the relationship was found to be weak, connoting that there are other factors aside budgetary participation which influence the realization of budget goals.

Malgwi \& Unegbu (2012), in investigating how budget performances in five selected states in Nigeria differ, concluded that there was significant difference in performance among the states, because of differences in the budgetary system, including differences in the level of budgetary participation. On the premises that the 


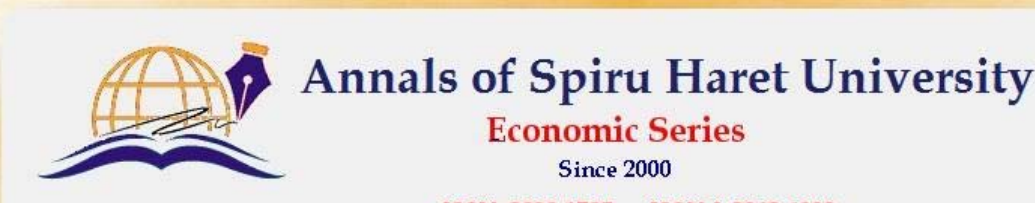

ISSN: 2393-1795 ISSN-L:2068-6900

\section{Issue 1/2018}

balance score card links budget strategy and objectives with Key Performance Indicators (KPI), they recommended a balanced score card approach to the preparation of budgets in the public sector, because budgets not only serve as a tool for revenue estimation and expenditure control, but also for checkmating corruption in the use of public resources. Akinniyi \& Ajibolade (2013) investigated the relationship between budgetary participation and organisational performance, using intrinsic motivation as a mediating variable, in fifteen federal government-owned universities in Nigeria. The study sampled the views of 272 unit heads using questionnaire as the primary data collection instrument. It was observed that though the direct relationship between budgetary participation and managerial performance was not statistically significant, budgetary participation positively and significantly impacted on intrinsic motivation; intrinsic motivation in turn positively and significantly impacted on organisational performance.

Proponents of a negative relationship between BP and MP often hinge their arguments on the situation organisations find themselves in [Hopwood, 1973; Brownell, 1982]. If the job was routine and mechanical, budgetary participation may negatively influence performance; if tasks are regarded as easy, employee may consider participation in budgeting unnecessary, ineffective, and consequently decrease performance when budgetary participation increase [Mia, 1989]. Others have maintained that employees exploit budgetary participation to create budgetary slacks because of the incongruence in organisational and individual goals [Stedry, 1960; Cyert \& March 1963; Schiff \& Lewin, 1970; Ajibolade \& Akinniyi, 2013]. According to them, budgetary slacks consequently lead to unfavourable performance, notwithstanding that a budget holder participated in budgeting.

\subsection{Theoretical framework}

\subsubsection{Theory of planned behaviour}

The theory of planned behaviour (TPB) was adopted to explain the nature of the relationship between budgetary participation (BP) and managerial performance (MP), specifically how BP influences MP (BP » MP). The theory of planned behaviour, which posits that people's behaviour can be deliberated and planned, helps to understand how people's behaviour can be influenced [Ajzen \& Fishbein, 1980; Canary \& Seibold, 1984; Ajzen, 1988; Sheppard, Hartwick, \& Warshaw, 1988; Ajzen, 1991]. According to the theory, perceived behavioural control and behavioural intention can be used to directly predict behavioural achievement. The theory proposes that people's behaviours are guided by three considerations which are behavioural beliefs, normative beliefs, control beliefs. These are expounded below: 

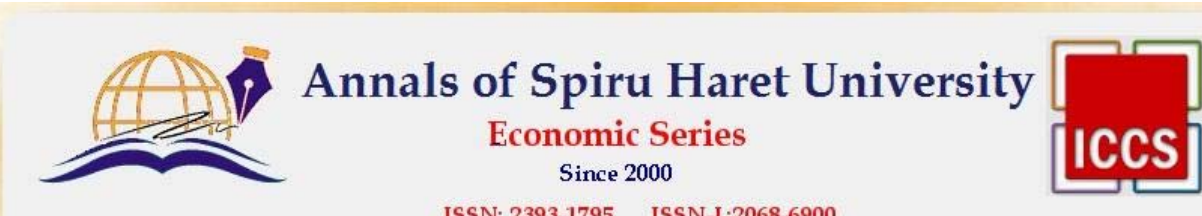

ISSN: $2393-1795 \quad$ ISSN-I-2068-6900

Issue 1/2018

(a) Behavioural beliefs refer to the beliefs about the likely consequences of the behaviour adoption.

(b) Normative beliefs are the beliefs about the expectations of others from the actor or individual.

(c) Control beliefs are beliefs about the presence of factors that may facilitate or impede performance of behaviour adoption.

The theory explains how budgetary participation affects managerial performance thus:

\section{Behavioural beliefs}

Participating in budgeting is behavioural. Managers will expectedly participate in budgeting to the extent that it is believed to influence their performances. Stated differently, managers will participate more in budgeting if it is believed to enhance their performance, but will participate less in budgeting if it is believed it will contribute little to their performances.

\section{Normative beliefs}

Normative belief relates to subjective norm, i.e. how individual's behaviour is influenced by the society or environment: for example, the perceived social pressure to perform or not to perform the behaviour [Adeyeye, 2013]. This is relevant to this study because the extent to which managers will participate in budgeting is dependent on their perception or normative belief as to the extent to which it will affect their performance.

\section{Control beliefs}

Budgets serve various purposes including control purposes. A manager may therefore achieve easy compliance amongst subordinates through budgets because in the public sector, once budgets are approved, it becomes sacrosanct to implement them [Omolehinwa \& Naiyeju, 2015]. As such, a manager sees the existence of budgets as a control factor that ensures compliance among subordinates and facilitates performance. It is to be expected, therefore, that a manager who wants to achieve control through budgets will participate more in budgetary activities, to improve performance in his/her unit or department, which is advertently a reflection of the manager's own performance. In other words, the presence of budgets is seen as a factor that facilitate performance, hence the dependence of managerial performance on budgetary participation. 


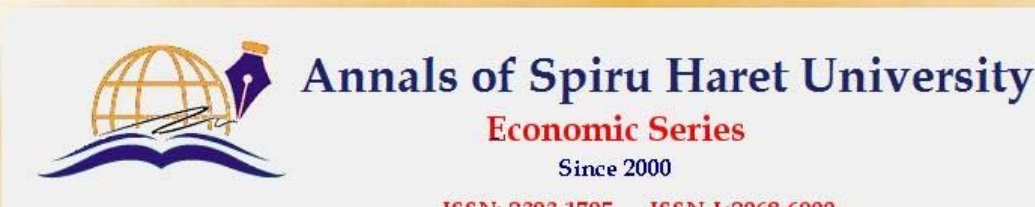

ISSN: 2393-1795 ISSN-L:2068-6900

Issue 1/2018

\subsubsection{Vroom's expectancy theory}

The expectancy theory conceptualised by Victor Vroom states that humans act according to their conscious expectations that a behaviour will lead to some specific outcomes or goals [Mullins \& Christy, 2013]. Vroom proposed three components of the expectancy theory which are (i) expectancy (the belief of the person that his/her effort will result in a desired outcome or performance), (ii) instrumentality (the belief of the person that he/she will be rewarded if the performance is met), and (iii) valence (the value of the reward according to the reckoning of the person).

To situate the expectancy theory in the context of the relationship between BP and MP, managers will consciously participate in budgeting if they expect that it will favourably affect their performance. If they reckon that participating in budgeting (the behaviour) will improve their performance (specific goal), then they will participate more. Going by the interaction between budgetary participation and managerial performance as documented in extant literature [Agbejule \& Saarikoski, 2006; Frucot \& White, 2006; Chong \& Chong, 2002; Nouri \& Parker, 1998; Brownell \& McInnes, 1986], it is hypothesized that:

$H_{1}$ : Budgetary participation has a significant impact on managerial performance in public sector organisations in Nigeria.

\section{Research methods}

\subsection{Population, sampling method and data collection procedure}

The study adopted a quantitative survey research design. The population of the study consists of the unit heads and departmental heads with budget responsibilities (equivalent to managers and senior managers respectively in private sector organisations) of five government-owned organisations located in Abuja, the Nigeria Federal Capital Territory (FCT). The five government-owned organisations are The Nigerian Electricity Regulatory Commission (NERC), The Federal Communications Commission (FCC), The Federal Inland Revenue Service (FIRS), Nigerian Investment Promotion Commission (NIPC), and Asset Management Corporation of Nigeria (AMCON). These organisations were selected because they are wellstructured and accessible. The choice of Abuja as the area of study stems from the fact that it is the capital of Nigeria and all Federal Ministries, Department and Agencies have their headquarters in Abuja. Little, Magner \& Welker (2002) supported by Khin (2010) suggested that organisations to be included for budgetary participation studies should be well-structured, decentralised, and budget holders should have budgetary responsibilities. 


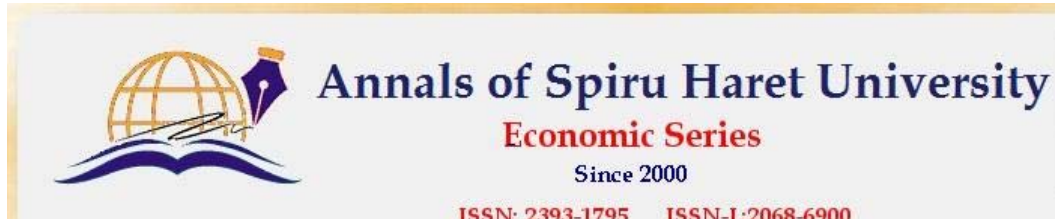

ISSN: 2393-1795 ISSN-L-2068-6900

Issue 1/2018

Primary data were collected from respondents, using a questionnaire as the research instrument. This design was considered appropriate to achieve the objectives of the study, because the study focused on perceptual issues on budgetary participation and employee performance. The study employed a multi-stage sampling technique, using a combination of probabilistic and non-probabilistic sampling techniques. First, the judgemental sampling technique was applied in generating a list of unit and departmental heads with budget responsibilities, obtained from the human resource departments of the selected organisations.

The total number of unit heads that satisfied the inclusion criterion was 376 in the five organisations. Next, 270 (representing $\approx 72 \%$ ) unit heads were randomly selected from the list of budget holders, whilst also ensuring that a minimum of $61.8 \%$ sample was drawn across each organisation. 192 copies of the instrument were retrieved, but 174 copies (representing 64\%) were found useable for analysis; this number is considered satisfactory, in line with Henri (2006). Statistics per distribution of copies of the research instrument among respondents is furnished in Appendix 1. The combined usage of the probabilistic and non-probabilistic (the multi-stage sampling) is also justified, claiming the limitation of one sampling technique is counteracted by the strength of the other sampling technique [Creswell, 2009]. Similar, earlier studies [Yuen, 2007; Frank, 2008; Luarn \& Huang, 2009; Akinniyi \& Ajibolade, 2013] have used this approach to select sample.

\subsection{The research instrument}

The research instrument was a multi-item questionnaire, segmented into three sections. The first section (Q1) of the questionnaire measured 'budgetary participation' and featured 6 items, adapted from Frucot \& White (2006); and LeachLopez, Stammer \& McNair (2007). Responses to items on budgetary participation were measured on a 7-point calibrated scale, ranging from strongly disagree (assigned code 1) to strongly agree (assigned code 7). The second section (Q2) measured 'managerial performance' using 8 variables, adapted from Maiga (2005) and Frucot \& White (2006). Responses to statements on managerial performance were also calibrated on a 7-point scale, ranging from 1 (below average) to 7 (outstanding performance). The third section (Q3) captured respondents' demographics considered to influence their views such as gender, age bracket, educational qualification, managerial cadre, department/function, length of time spent in position held, and length of time spent in organisation. 
Issue 1/2018

\subsection{Model specification}

The Ordinary Least Square (OLS) models in equations 1 and 2 were formulated upon theoretical and empirical underpinnings established in literature as to the relationship between BP and MP.

\section{Model 1}

$$
\begin{aligned}
& P L N=\alpha_{01}+\alpha_{1} B P+\alpha_{\mathrm{et} 1} \\
& I N V=\alpha_{02}+\alpha_{2} B P+\alpha_{\mathrm{et} 2} \\
& C O O=\alpha_{03}+\alpha_{3} B P+\alpha_{\mathrm{et} 3} \\
& E V A=\alpha_{04}+\alpha_{4} B P+\alpha_{\mathrm{et} 4} \\
& S U P=\alpha_{05}+\alpha_{5} B P+\alpha_{\mathrm{et} 5} \\
& S T F=\alpha_{06}+\alpha_{6} B P+\alpha_{\mathrm{et} 6} \\
& N E G=\alpha_{07}+\alpha_{7} B P+\alpha_{\mathrm{et} 7} \\
& R E P=\alpha_{08}+\alpha_{8} B P+\alpha_{\mathrm{et} 8}
\end{aligned}
$$

Where:

$\begin{array}{ll}\text { PLN: } & \text { Planning } \\ \text { INV: } & \text { Investigating } \\ \text { COO: } & \text { Co-ordinating } \\ \text { EVA: } & \text { Evaluating } \\ \text { SUP: } & \text { Supervising } \\ \text { STF: } & \text { Staffing } \\ \text { NEG: } & \text { Negotiating } \\ \text { REP: } & \text { Representing } \\ \alpha_{01-8}: & \text { Constant } \\ \alpha_{1-8}: & \text { Regressor Coefficients } \\ \alpha_{\text {et1-8 }} & \text { Stochastic error term }\end{array}$

\section{Model 2}

$$
\begin{aligned}
& M P=f(B P) \\
& M P=\mu_{0}+\mu_{1} B P+\mu_{\mathrm{et}}
\end{aligned}
$$

Where:

MP: $\quad$ Managerial Performance 


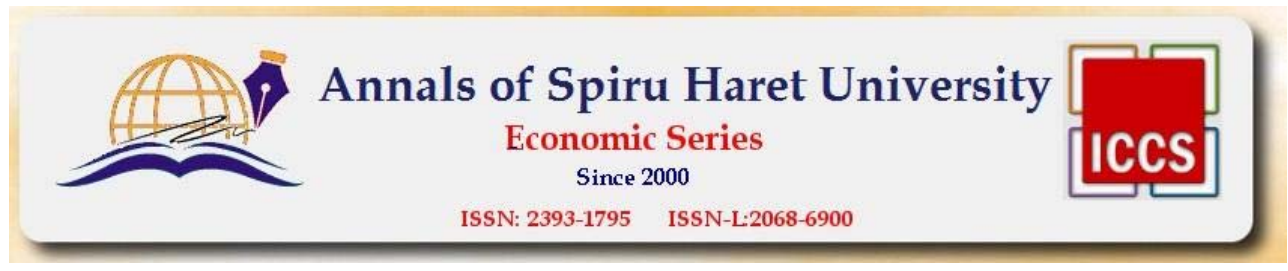

Issue 1/2018

$\begin{array}{ll}\text { BP: } & \text { Budgetary Participation } \\ \mu_{0:} & \text { Constant } \\ \mu_{1:} & \text { Regressor Coefficient } \\ \mu_{\text {et: }} & \text { Stochastic error term }\end{array}$

A priori expectation of relationships between the dependent and independent variables are placed in parenthesis below the independent variable correlates in equations 1.1 and 2.1 respectively.

The evaluation of model fitness was triangulated using the model ANOVA $p$ value, and a comparison of the Standard Error (SE) of Mean to the Mean of the Dependent Variable (DV). A model with $p$ value $\leq 0.05$ is generally regarded as significant, and a model with SE of mean $<$ Mean of DV is regarded as being fit [Bordens \& Abbott, 2002; Avwokeni, 2014].

\subsection{Reliability test and data analysis techniques}

Descriptive statistics including frequencies, Minimum value, Maximum value, Mean (M), and Standard Deviation (SD) were used to analyse the data. The score of all the six items used to measure budgetary participation were summed up and averaged to derive an overall mean score for budgetary participation (BP). Reliability test for BP using the Cronbach's alpha, yielded a coefficient of 0.727 (Appendix 2), which is above the recommended threshold of 0.7 considered satisfactory [Nunnally, 1978]. Factor Analysis was used to reduce the number of attributes for managerial performance (MP), which initially had eight items. The selection of variables was at a threshold of 0.3 [Kaiser, 1974]. Cronbach's alpha reliability test coefficient before factor-analysing MP was 0.773 , but this improved to 0.788 after factor analysis (Appendix 2).

Test for normality was carried out using the one-sample Kolmogorov-Smirnov (KS) $\mathrm{Z}$ statistics. Both variables had $\mathrm{p}$ value less than 0.01 (BP, $\mathrm{p}$ value $=0.002 ; \mathrm{MP}$, $\mathrm{p}$ value, $=0.004$ ), implying non-normal distribution (Appendix 3). As a result, analysis of difference in opinion on BP and MP was carried out using the KruskalWallis non-parametric statistics to further examine the dispersion in opinion of respondents on the level of participation in budgeting, and rating on managerial performance. Length of time spent in organisation was used as the grouping variable in the Kruskal-Wallis analysis because it is suspected that this could influence respondents' perception on BP and MP. Correlation and regression techniques were applied to examine the nature of relationship between BP and MP variables. The Pearson Correlation coefficient (r) was used to gauge the direction (positive or negative), strength (weak or strong) and statistical significance of relationship 


\section{Issue 1/2018}

between variables. Regression analysis was used to draw inference on the impact of the independent variable (IV) on the dependent variable (DV) using the Model ANOVA, coefficient of determination ( $\mathrm{R}$ square), and the regressor coefficients in line with Luarn \& Huang (2009). Adapting Cohen's (1988) guide, a framework for the interpretation of correlation coefficients and coefficients of determination was developed for the study (appendix 8). Data analysis was aided by SPSS 23 software.

\section{Results}

\subsection{Respondents' demographics}

Results from the analysis of respondents' characteristics are presented in Tables 1 and 2.

Table no. 1. Characteristics of Respondents

\begin{tabular}{|c|c|c|c|c|}
\hline Variable & Category & Freq. & $\%$ & Total \\
\hline \multirow[t]{2}{*}{ Gender } & Male & 112 & 64.4 & \\
\hline & Female & 62 & 35.6 & 174 \\
\hline \multirow[t]{2}{*}{ Age Group } & $(31-40)$ Years & 76 & 43.7 & \\
\hline & $(41-50)$ Years & 98 & 56.3 & 174 \\
\hline \multirow[t]{4}{*}{ Educational Qualification } & First Degree only & 11 & 6.3 & \\
\hline & Second Degree only & 64 & 36.8 & \\
\hline & First Degree with professional & 89 & 51.1 & \\
\hline & $\begin{array}{l}\text { Second Degree with } \\
\text { professional }\end{array}$ & 10 & 5.7 & 174 \\
\hline \multirow[t]{2}{*}{ Position in Organisation } & $\begin{array}{l}\text { Senior manager (Depart. } \\
\text { Head) }\end{array}$ & 70 & 40.2 & \\
\hline & Junior manager (Unit Head) & 104 & 59.8 & 174 \\
\hline \multirow[t]{6}{*}{ Department/Function } & Finance \& Accounts & 77 & 44.3 & \\
\hline & Human resources & 12 & 6.9 & \\
\hline & Public Relations & 13 & 7.5 & \\
\hline & Procurement & 17 & 9.8 & \\
\hline & Information Technology & 14 & 8.0 & \\
\hline & Customer Service & 41 & 23.6 & 174 \\
\hline \multirow{2}{*}{$\begin{array}{l}\text { Length of time spent in } \\
\text { Position held }\end{array}$} & $(0-3)$ Years & 68 & 39.1 & \\
\hline & (4-7) Years & 106 & 60.9 & 174 \\
\hline \multirow{4}{*}{$\begin{array}{l}\text { Length of time in } \\
\text { Organisation }\end{array}$} & (0-3) Years & 18 & 10.3 & \\
\hline & (4-7) Years & 41 & 23.6 & \\
\hline & (8-12) Years & 62 & 35.6 & \\
\hline & $(13-18)$ Years & 53 & 30.5 & 174 \\
\hline
\end{tabular}




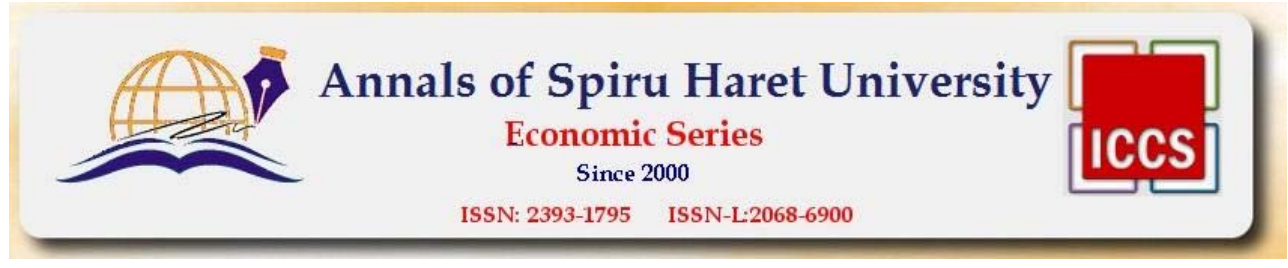

Issue 1/2018

Table no. 2. Descriptive Statistics of Respondents' Characteristics

\begin{tabular}{|l|r|r|r|r|}
\hline Demographic variable & N & Minimum & Maximum & Mean \\
\hline Age Group & 174 & 2 & 3 & 2.56 \\
Education Qualification & 174 & 1 & 5 & 3.13 \\
Length of time spent in position held & 174 & 1 & 2 & 1.61 \\
Length of time in the organisation & 174 & 1 & 4 & 2.86 \\
Valid N (listwise) & 174 & & \\
\hline
\end{tabular}

Summary statistics on the demographic variables shown in Tables 1 and 2 reveals that Age has a Mean score of 2.56, implying that on the average, respondents were within the age bracket of labels 2 ( 31 to 40 years) and label 3 (41 to 50 years). The average length of time spent in organisations was between label 2 (4 to 7 years) and label 3 ( 8 to 12 years). The average length of time spent in position was between 0 to 7 years. The average qualification held by respondents was First degree plus relevant professional qualification. The result of the demographic characteristics on respondents' age, educational qualification, position in the organisation (managerial cadre), department, length of time spent in role, and length of time spent in organisation give a reasonable level of assurance that respondents who participated in the survey were experienced, and possess the technical competence to provide answers to the items in the research instrument.

\subsection{Level of managers' participation in budgeting}

The overall mean of BP was computed using the six variables, as they all loaded in component 1 after performing exploratory factor analysis.

BP has a Minimum score of 5 and a Maximum score of 7 (appendix 7). The Mean score of 6.08 represents $86.9 \%$ on a 7-point calibrated scale. The SD of 0.327 , indicating low dispersion of score from the Mean, implies a strong consensus on the level of budgetary participation in government-owned institutions. Further, KruskalWallis test result confirms no significant difference in opinion of respondents based on their work experience $(p=0.751)$ [appendix 4]. On the strength of these results, it is concluded that the level of managers' participation in budgeting in public sector organisations in Nigeria is high (research objective one).

\subsection{Relationship between budgetary participation and managerial functions}

Results from analysis of the relationship between Budgetary Participation and the eight Managerial Functions are contained in Tables 3 and 4. 
Table no. 3. Correlation between Budgetary Participation and Managerial functions

\begin{tabular}{|c|c|c|c|c|c|c|c|c|}
\hline $\mathrm{MF}$ & Planning & Investigating & $\begin{array}{c}\text { Co- } \\
\text { ordinating }\end{array}$ & Evaluating & Supervising & Staffing & Negotiating & Representing \\
\hline $\begin{array}{l}\text { Budgetary Pearson } \\
\text { ParticipationCorrelation }\end{array}$ & $0.374^{* * *}$ & $0.204^{* *}$ & $0.262^{* *}$ & $0.247^{* *}$ & $0.263^{*}$ & $0.209^{*}$ & 0.117 & 0.043 \\
\hline $\begin{array}{l}\text { Sig. (2- } \\
\text { tailed) }\end{array}$ & 0.000 & 0.007 & 0.000 & 0.001 & 0.000 & 0.006 & 0.123 & 0.571 \\
\hline
\end{tabular}

Correlation result in Table 3 shows that budgetary participation has a positive, significant relationship with six of the eight managerial functions, including planning $(\mathrm{r}=0.374, \mathrm{p}=0.000)$, investigating $(\mathrm{r}=0.204, \mathrm{p}=0.007)$, co-ordination $(\mathrm{r}=0.262, \mathrm{p}$ $=0.000)$, evaluating $(\mathrm{r}=0.247, \mathrm{p}=0.001)$, supervising $(\mathrm{r}=0.263, \mathrm{p}=0.000)$ and staffing $(r=0.209, p=0.006)$. However, the strength of relationship between budgetary participation and planning (evincing the highest coefficient in Table 3 ) is moderate at $37.4 \%$.

Establishing that there is significant relationship between budgetary participation and most of the managerial functions, further analysis was performed to assess the impact of budgetary participation on each of the managerial functions using regression analysis. Results are summarised in Table 4.

Table no. 4. Summary of Regression Results on the Impact of Budgetary Participation on Managerial Functions

\begin{tabular}{|c|c|c|c|c|}
\hline \multirow{2}{*}{ Model No. } & \multirow{2}{*}{$\begin{array}{l}\text { Dependent } \\
\text { Variable }\end{array}$} & \multirow{2}{R}{\begin{tabular}{l} 
Square \\
\cline { 3 - 5 }
\end{tabular}} & Coefficients (Unstandardised) \\
\hline $1.1^{* * *}$ & Planning & 0.140 & $0.286(0.790)$ & $0.929(0.000)$ \\
\hline $1.2^{* * *}$ & Investigating & 0.042 & $2.835(0.013)$ & $0.506(0.007)$ \\
\hline $1.3^{* * *}$ & Co-ordinating & 0.069 & $2.967(0.002)$ & $0.539(0.000)$ \\
\hline $1.4^{* * *}$ & Evaluating & 0.061 & $2.725(0.008)$ & $0.555(0.001)$ \\
\hline $1.5^{* * *}$ & Supervising & 0.069 & $2.474(0.015)$ & $0.595(0.000)$ \\
\hline $1.6^{* * *}$ & Staffing & 0.044 & $3.801(0.000)$ & $0.395(0.006)$ \\
\hline 1.7 & Negotiating & 0.014 & $4.584(0.000)$ & $0.249(0.123)$ \\
\hline 1.8 & Representing & 0.002 & $5.453(0.000)$ & $0.090(0.571)$ \\
\hline
\end{tabular}




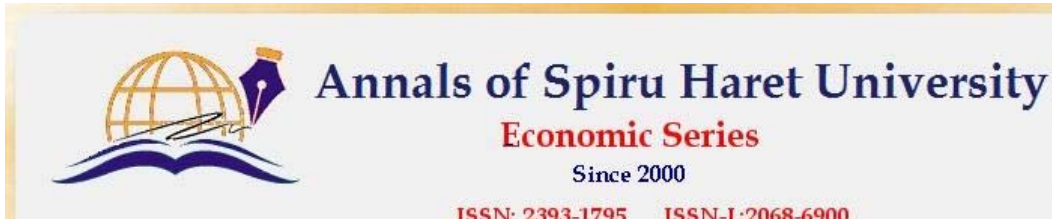

ISSN: 2393-1795 ISSN-I-2068-6900

Issue 1/2018

Models 1.1 to 1.6 are statistically significant at $1 \%$. The dependent variable in each of these Models is the six managerial function measures that recorded a significant relationship with budgetary participation in Table 3, thus corroborating the significant relationship between budgetary participation and managerial function. Models 1.7 and 1.8 having negotiating and representing as dependent variables are not significant - these two variables do not significantly correlate with budgetary participation as well (Table 3), and the coefficients of budgetary participation (as the independent variable in the Models) do not assume statistical significance (Table 4). Hence, budgetary participation does not correlate with negotiating and representing.

The coefficients of determination (R square) in Table 4 connote that budgetary participation predicts changes in planning $(14.0 \%)$, co-ordinating $(6.9 \%)$, supervising (6.9\%), evaluating (6.1\%), staffing (4.4\%), and investigating (4.2\%). The coefficients of budgetary participation for these six items are positive and statistically significant at $1 \%$, thus reinforcing the positive significant impact of budgetary participation on managerial functions. A close inspection of the regressor coefficients reveals that, although the coefficient of the constant in Model 1.1 (with planning as the dependent variable $)$ is low $\left(\alpha_{01}=0.286\right)$ and not statistically significant $(\mathrm{p}=0.790)$, the coefficient of budgetary participation in this model is the highest $\left(\alpha_{1}=0.929, \mathrm{p}=\right.$ $000)$, and the Model recorded the highest coefficient of determination $(\mathrm{R}$ square $=$ 0.140). In effect, budgetary participation has marked impact on planning, as the constant has a low and insignificant impact. To summarise, $14 \%$ of effective planning is attributable to active participation in budgeting. While the impact of budgetary participation on planning is adjudged moderate, its impact on coordinating, supervising, evaluating, staffing, and investigating is considered weak (research objective two).

\subsection{Impact of budgetary participation on managerial performance}

\subsubsection{Factor analysis of managerial performance}

To reduce the number of variables under managerial performance (having 8 items), exploratory factor analysis (EFA) was employed, using 0.30 as the cut-off. The Kaiser-Meyer-Olkin (KMO) and Bartlett's Test help to measure the strength of the relationship among variables [Nunnally, 1978]. The KMO measures the adequacy of the sampling, and coefficient should be generally greater than 0.5 for a factor analysis to be valid [Kaisen, 1974]. The principal component analysis (PCA) extraction method, with varimax rotation method, and Kaiser normalisation procedure was utilised. 


\section{Issue 1/2018}

Managerial Performance has KMO coefficient of 0.503 and Bartlett's sphericity test of $p=0.030 \leq 0.05$, thus confirming its factorability (appendix 6a). Table of total variance explained presents all the factors extractable from the analysis along with their Eigen values (appendix 6b). It also explains the \% of variances for the components having Initial Eigen values of a minimum of 1.0. The first factor accounts for $16.409 \%$ of the variance; the second, $14.290 \%$; the third, $12.979 \%$; and the fourth, $11.816 \%$. Since component 1 has the highest magnitude of variance explained (16.409\%), variables that loaded on this component satisfying the 0.30 threshold were selected.

Table no. 5. Rotated Component Matrix ${ }^{\mathrm{a}}$ for Managerial Performance

\begin{tabular}{lcccc}
\hline \hline & \multicolumn{3}{c}{ Component } \\
\cline { 2 - 5 } Variable & \multicolumn{1}{c}{2} & 3 & 4 \\
\hline Planning & 0.355 & 0.175 & 0.006 & 0.124 \\
Investigating & 0.703 & 0.129 & 0.249 & -0.154 \\
Co-ordinating & 0.745 & -0.119 & -0.236 & 0.077 \\
Evaluating & 0.098 & -0.174 & -0.093 & 0.682 \\
Supervising & 0.281 & -0.061 & 0.747 & 0.072 \\
Staffing & -0.031 & 0.211 & 0.072 & 0.781 \\
Negotiating & 0.272 & -0.033 & -0.718 & 0.095 \\
Representing & 0.024 & 0.760 & 0.038 & 0.007 \\
\hline \% of variance explained & 16.409 & 14.290 & 12.979 & 11.816 \\
\hline \hline
\end{tabular}

Extraction Method: Principal Component Analysis.

Rotation Method: Varimax with Kaiser Normalization.

${ }^{a}$ Rotation converged in 5 iterations.

The three items highlighted in component 1 (Table 5) emerged from EFA, including Planning, Investigating and Co-ordinating, meaning they have some correlations amongst themselves as to coherently represent Managerial Performance. Meanwhile, budgetary participation had a significant impact on these three variables. Commenting on other components, one item (representing) loaded on component 2, having $14.290 \%$ variance explained. While supervising loaded on component 3 with $12.979 \%$ of variance explained, evaluating and staffing loaded on component 4 , with 


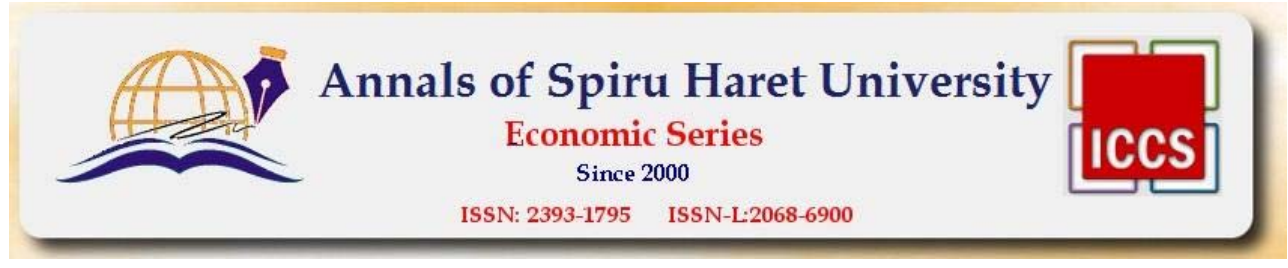

Issue 1/2018

$11.816 \%$ of variance explained. Overall, the five variables which did not satisfy the selection criteria that were consequently dropped include: Evaluating, Supervising, Staffing, Negotiating, and Representing. Two of these variables (negotiating and representing) have no significant relationship with budgetary participation though.

The descriptive statistics of Managerial Performance (MP), computed using the three items that were retained from component 1, is reported in appendix 7. MP has a Minimum and Maximum score of 5 and 7 respectively. The Mean score is 6.03, an equivalent of $86.1 \%$ over a 7 -point scale calibration. It is inferable from these statistics that respondents consider themselves as performing well above average in their managerial responsibilities. The SD of 0.494 (appendix 7), and Kruskal-Wallis $\mathrm{p}=0.878>0.05$ (appendix 4), reinforces the consensus among respondents in this regard.

4.4.2. Partial correlation analysis - relationship between budgetary participation and managerial performance

Partial correlation analysis was carried out to examine the direction, strength and the statistical significance of the relationship between Budgetary Participation (BP) and Managerial Performance (MP), after taking out the effect of relevant demographic variables. Length of time in position held \& length of time in organisation (proxies for 'length of experience'); and educational qualifications were used as control variables. Result is presented in Table 6.

Table no. 6. Partial Correlation Analysis between BP and MP

\begin{tabular}{lrr}
\hline \hline \multicolumn{1}{c}{ Control Variables } & \multicolumn{1}{c}{$\begin{array}{c}\text { Managerial } \\
\text { Performance }\end{array}$} \\
\hline $\begin{array}{l}\text { Length of time in position } \\
\text { held \& Length of time in }\end{array}$ & 0.442 \\
$\begin{array}{llr}\text { the company \& Education } \\
\text { Qualification }\end{array}$ & Significance (2-tailed) & 0.000 \\
\hline
\end{tabular}

The relationship between $\mathrm{BP}$ and $\mathrm{MP}$, after controlling for the effect of respondents' experience and educational qualification, is positive, moderate, and statistically significant at $1 \%(\mathrm{r}=0.442, \mathrm{p}=0.000 \leq 0.01)$. The strength of relationship of budgetary participation and managerial performance is moderate at $44.2 \%$. 
Issue 1/2018

4.4.3. Regression analysis - impact of budgetary participation on managerial performance

To further assess the influence of budgetary participation on overall managerial performance, regression analysis was carried out in respect of Model 2, and the results reported in Tables $7 \mathrm{a}$ and $7 \mathrm{~b}$.

Table no. 7a. Regression Test Results for Model 2

\begin{tabular}{|c|c|c|c|c|c|c|c|}
\hline \multirow[b]{2}{*}{ Model } & \multirow[b]{2}{*}{$\mathrm{R}$} & \multirow[b]{2}{*}{$\begin{array}{c}\mathrm{R} \\
\text { Square }\end{array}$} & \multirow[b]{2}{*}{$\begin{array}{c}\text { Adjusted R } \\
\text { Square }\end{array}$} & \multirow{2}{*}{$\begin{array}{l}\text { Std. Error } \\
\text { of the } \\
\text { Estimate }\end{array}$} & \multicolumn{3}{|c|}{ Change Statistics } \\
\hline & & & & & $\begin{array}{l}\text { R Square } \\
\text { Change }\end{array}$ & $\begin{array}{l}\text { F } \\
\text { Change df1 df2 }\end{array}$ & $\begin{array}{l}\text { Sig. F } \\
\text { Change }\end{array}$ \\
\hline 2 & $0.437^{\mathrm{a}}$ & 0.191 & 0.186 & 0.445 & 0.191 & $40.509 \quad 1172$ & 0.000 \\
\hline
\end{tabular}

Table no. 7b. Regression Coefficients ${ }^{\mathrm{a}}$ for Model 2

\begin{tabular}{|c|c|c|c|c|c|c|c|c|}
\hline \multirow{2}{*}{\multicolumn{2}{|c|}{ Model }} & \multicolumn{2}{|c|}{$\begin{array}{l}\text { Unstandardized } \\
\text { Coefficients }\end{array}$} & \multirow{2}{*}{$\begin{array}{c}\begin{array}{c}\text { Standardized } \\
\text { Coefficients }\end{array} \\
\text { Beta }\end{array}$} & \multirow[b]{2}{*}{$\mathrm{t}$} & \multirow[b]{2}{*}{ Sig. } & \multicolumn{2}{|c|}{$\begin{array}{l}\text { Collinearity } \\
\text { Statistics }\end{array}$} \\
\hline & & B & $\begin{array}{l}\text { Std. } \\
\text { Error }\end{array}$ & & & & Tolerance & VIF \\
\hline \multirow[t]{2}{*}{2} & (Constant) & 2.029 & 0.630 & & 3.222 & 0.002 & & \\
\hline & BP & 0.658 & 0.103 & 0.437 & 6.365 & 0.000 & 1.000 & 1.000 \\
\hline
\end{tabular}

${ }^{\mathrm{a}}$ Dependent Variable: MP

Model 2 has ANOVA p $=0.000 \leq 0.01$ (Appendix 5), meaning the model is statistically significant at $1 \%$. The Standard Error of the estimate (0.445) is less than the Mean of the Dependent Variable (6.08), which establishes the Model fitness. The variance inflation factor (VIF) and tolerance statistics indicate that there is no collinearity problem between dependent variable and the independent variable. A VIF less than 10 indicates that there is no multi-collinearity problem among the independent variables [Stevens, 2002]. The Model has R square of 0.191 (Table 7a), meaning $19.1 \%$ of the changes in managerial performance is attributable to budgetary participation. The remaining $80.9 \%$ is the error term $\left(\mu_{\mathrm{et}}\right)$, which refers to extraneous variables outside the model affecting managerial performance. The constant $\mu_{0}(\mathrm{p}=0.002 \leq 0.01)$ is significant at $1 \%$. The unstandardised beta of BP $\left(\mu_{1}\right.$ 64 

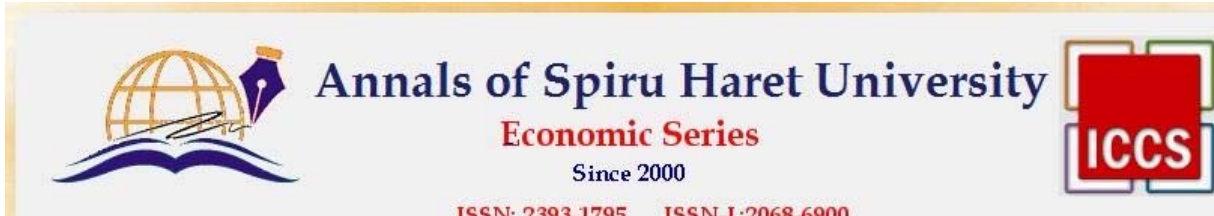

ISSN: $2393-1795 \quad$ ISSN-L-2068-6900

Issue 1/2018

$=0.658, \mathrm{p}=0.000 \leq 0.01)$ is positive and significant at $1 \%$ (Table $7 \mathrm{~b})$, corroborating the positive significant relationship between BP and MP observed from correlation analysis (Table 6). Inferring from these results, we conclude that the impact of budgetary participation on managerial performance is positive, significant and moderate (research objective three).

\subsection{Test of hypothesis}

Result from partial correlation analysis in Table 6 confirms the relationship between BP and MP to be positive and statistically significant at $1 \%(r=0.442, p=$ $0.000 \leq 0.01)$. Also, when BP was regressed on MP in Model 2, result shows the beta of BP $\left(\mu_{1}=0.658, p=0.000 \leq 0.01\right)$ ) to be positive and significant at $1 \%$ (Table 7b). In addition, budgetary participation had a significant impact on six of the eight managerial functions (Table 4). It is therefore concluded that budgetary participation has a significant impact on managerial performance in public sector organisations in Nigeria.

\section{Discussion}

It was observed that budgetary participation and planning correlates at $37.4 \%$ (highest correlation coefficient in Table 3), and budgetary participation explains $14 \%$ of the variation in planning (Table 4 ). This could be interpreted that of all the managerial performance measures, budgetary participation exerts the most on planning. The budgetary process involves steps such as planning, co-ordinating, controlling, amongst others. Participating in the budgeting process will require managers to get involved in the budgeting activities such as active participation in setting the budgets, making necessary inputs and relevant contributions through the expression of opinion. When the estimates are approved by the National Assembly, it becomes budget, and it is used to assess performance of managers. Participation in budgetary activities presents managers with the opportunity to contribute their inputs such that before the budget is finally agreed upon and eventually approved, they can express the areas they are comfortable with and the areas of concern, to avoid a situation whereby managers feel the budgets are imposed upon them without their consultation and consent. This phenomenon may therefore explain the high level of budgetary participation observed in public sector organisations in Nigerian (research objective one)

Considering that budgeting is used to carry out managerial responsibilities, how well a manager performs depends on the extent of budgetary participation because of the managerial roles which budgeting performs such as planning, 


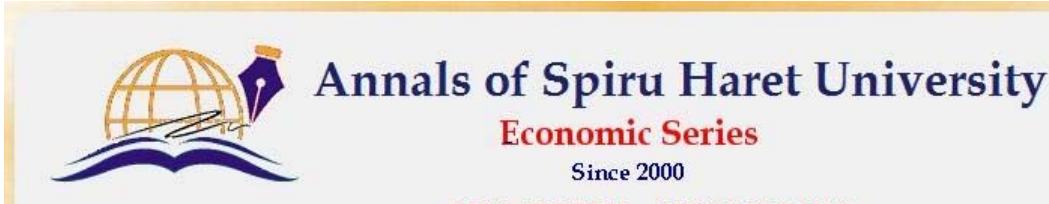

ISSN: 2393-1795 ISSN-L:2068-6900

\section{Issue 1/2018}

controlling, co-ordinating, evaluating. For example, managers that plan the expenditure in their departments by participating in budgeting will be greatly aided in a way in their overall planning because the requirements to submit annual budgets will cause them to do a holistic review of the activities to be carried out in the department for the year. Since some budgets may be prepared based on activities to be carried out (modern budgeting techniques such as PPBS, ZBB and $\mathrm{ABB}$ supports this philosophy), managers will have to identify the activities for the year, and the underlying budget estimates for the activities: thus, budget preparation, advertently reinforces planning. A manager can also use budgets for co-ordination of activities and evaluation of performance. When actual performances are measured and compared with standards contained in a budget (performance evaluation), variances can be identified, investigated and corrective actions taken to remedy the situation. Such actions, when taken, contribute to the effectiveness of a manager's supervision and task co-ordination. In summary, because of the overlap between the functions of budgeting and the roles involved in management, participating in budgeting affects the discharge of managerial functions in some ways (research objective two). Failure by managers to express their opinion concerning a budget, if it is too high or too low, when the opportunity to participate in budgeting presents itself will mean they are doing a great deal of disservice to themselves, because when the budget becomes approved, it will serve as a yardstick to assess, reward or punish the managers for good performance, under-performance or lack of performance. The consideration and consciousness that such budgets will be used to assess performances (whether they participate in budget-setting) should naturally spur managers to participate in budgeting, even if ordinarily they do not feel like doing so.

The regression result concerning the influence of budgetary participation on managerial performance (Model 2) addresses the third research objective. In Model 2 , the R square of 0.191 implies that budgetary participation influences managerial performance up to $19.1 \%$. Although $19.1 \%$ improvement in managerial performance is attributable to participation in budgeting, 14\% improvement in planning alone is accounted for by budgetary participation (Model 1.1). Whilst the influence of budgetary participation on managerial performance is positive and statistically significant, the impact is considered moderate. There are other factors affecting performances of managers in the government-owned institution aside participating in budgeting such as task-technology fit, computer self-efficacy, and utilisation of IT facilities [Luarn \& Huang, 2009]; and institutional factors such as incentives and goal clarity [Frank, 2008]. Likewise, Haenisch's (2012) study on 66 


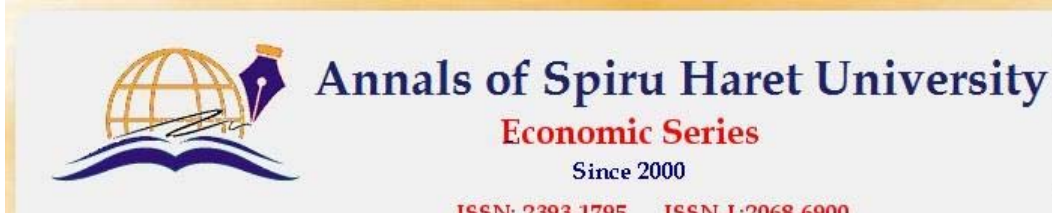

ISSN: 2393-1795 ISSN-L-2068-6900

Issue 1/2018

factors affecting the productivity of government workers in the United States of America empirically validated the influences of supervision and management; communication, recognition, training, technology, and volume of work on employees' performances in public sector organisations. The direct influence of budgetary participation on managerial performance, as indicated in the result of this study, aligns with the submissions of earlier studies that budgetary participation positively affects managerial performance in private sector organisations [Hofstede, 1968; Brownell, 1982; Nouri \& Parker, 1998; Wentzel, 2002; Adeyeye, Otusanya \& Uadiale, 2013], as well as in public sector organisations [Kochi, 2011; Malgwi \& Unegbu, 2012; Noor \& Othman, 2012; Owusu, Dwomoh, Collins, Yaa \& Daniel, 2014]. The result also validates the theories (theory of planned behaviour and expectancy theory) underpinning the influence of budgetary participation on managerial performance which suggest that how well a manager performs may be dependent on the level of involvement in budgeting activities. In summary, the level of managerial performance (especially the ability to effectively plan) may be dependent on the degree to which a manager participates in budgetary activities.

\section{Conclusions}

In response to the call for more research on budgetary participation and managerial performance in public sector organisations, this study investigates the level of participation in budgeting by managers (unit and departmental heads), the relationship between budgetary participation and managerial functions, and the impact of budgetary participation on managerial performance in public sector organisations in Nigeria. The study found that there is high level of budgetary participation by managers in public sector organisations in Nigeria. Although budgetary participation was observed to positively and significantly influence managerial functions such as planning, co-ordinating, supervising, evaluating, staffing, and investigating, it exerts the most on planning. The impact of budgetary participation on overall managerial performance appears to be moderate.

This paper contributes to knowledge in the way of closing the gap in literature on budgeting in the public sector, as empirical studies in this area are scanty. However, the results of the study should be interpreted with caution as limitations of survey research apply, especially social desirability bias, in which respondents give an answer that they perceive as being good or desirable rather than the correct answer. In addition, findings may be inapplicable to public sector organisations in other countries because of subsisting peculiarities inherent in 


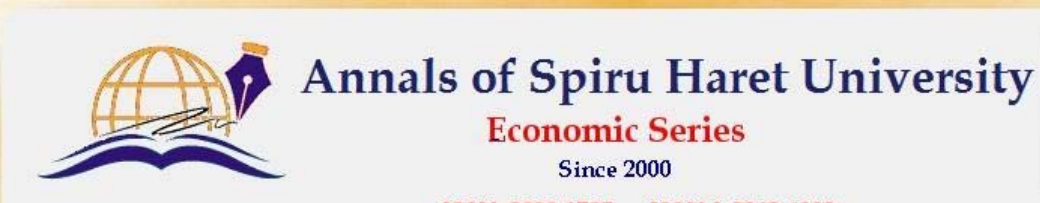

ISSN: 2393-1795 ISSN-L-2068-6900

\section{Issue 1/2018}

different domains. Since most studies have focused on the influence of BP on MP (BP»MP), further studies may investigate of the influence of MP on BP (MP»BP), and other factors, aside employee performance which may influence budgetary participation.

It is desirable that public sector organisations transit from incremental budgeting to sophisticated budgeting techniques such as ABB, ZBB, PPBS. However, getting employees more involved in the budgeting process is a step, which could gradually pave way for improvement in budgeting. Employees' motivation and deeper involvement in budget matters in the public sector could be the way out of the traditional budgeting quagmire that public-sector organisations are characteristically bedevilled with.

\section{REFERENCES}

Adams, R. A., Public Sector Accounting and Finance (Lagos: Corporate Publisher Venture, 2002).

Adeyeye, G. B., The impact of taxpayers' perception of good governance on voluntary tax compliance in Lagos State, Nigeria. Unpublished Thesis (Department of Accounting, University of Lagos, Nigeria, 2013).

Adeyeye, G. B., Otusanya, O. J. \& Uadiale, O. M., "Participatory budgeting and subordinates' performance: The Nigerian experience," Accounting Frontier, 4(2), (2013): 246-263.

Agbejule, A. \& Saarikoski, L., "The effect of cost management knowledge on the relationship between budgetary participation and managerial Performance," The British Accounting Review, 38, (2006): 427-440.

Ajibolade, S. O. \& Akinniyi, O. K., "The influence of organisational culture and budgetary participation on propensity to create budgetary slack in public sector organisations," British Journal of Arts and Social Sciences, 13(1), (2013): 69-83.

Ajzen, I., "The theory of planned behaviour," Organisational behaviour and human decision processes, 50(2), (1991): 179-211.

Ajzen, I. \& Fishbein, M., Understanding attitudes and predicting social behaviour (Englewood Cliffs, NJ: Prentice Hall, 1980).

Akinniyi, O. K. \& Ajibolade, S. O., "Budgetary participation and organisational performance in Nigerian federal Universities: The mediating effect of intrinsic motivation" Nigerian Journal of Management studies, 11(1/2), (2013): 122-135.

Avwokeni, A. J., Anatomy of research reports and presentation (Lagos: Unicampus Books, 2014). 


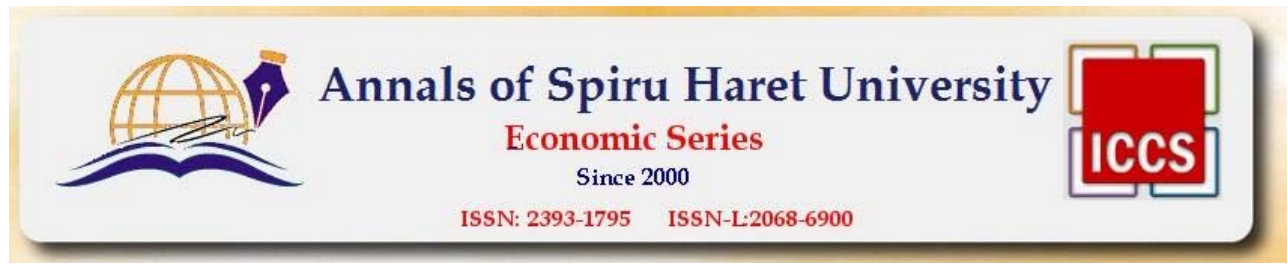

Issue 1/2018

Bameke, S. A., Public sector accounting and finance for decision-making (Lagos: Magic Plus Nigeria Limited, 2008).

Bordens, K. S. \& Abbott, B. B., Research design and methods: A process approach (Boston: McGraw-Hill, 2002).

Brownell, P., "Participation in budgeting process: When it works and when it doesn't," Journal of Accounting Literature, 1, (1982): 124-153.

Brownell, P. \& McInnes, M., "Budgetary participation, motivation and managerial performance," The Accounting Review, 4, (1986): 587-600.

Canary, D. J. \& Seibold, D. R., Attitudes and behaviour: An annotated bibliography (New York: Praeger, 1984).

Chong, V. K. \& Chong, K. M., "The role of feedback on the relationship between budgetary participation and performance," Pacific Accounting Review, 24 (2), (2002): 33-55.

CIMA, Chartered Institute of Management Accountants Official Terminology (London: CIMA Publishing/Elsevier, 2005).

CIMA, Managerial Paper 2: Management accounting - Decision making (London: BPP Learning Media Ltd, 2008).

Creswell, J. W., Research design: Qualitative, quantitative and mixed methods approaches (USA: Sage Publications Inc., 2009).

Cyert, R. M. \& March, J. G., A behavioral theory of the firm (Englewood Cliffs, NJ: Prentice Hall, 1963).

Frank, H. M., "Performance management practices in public sector organisations; impact on performance," Accounting, Auditing \& Accountability Journal, 21(3), (2008): 427-454.

Frucot, V. \& White, S., "Managerial levels and the effects of budgetary participation on managers," Managerial Auditing Journal, 21(2), (2006): 191-206.

Greenberg, P. S. \& Greenberg, R. H., "Who needs budgets?: You do," Strategic Finance, 88(2), 4, (2006): 1-45.

Haenisch, J. P., Factors affecting the productivity of government workers. Retrieved from http://classic.sgo.sagepub.com (2012).

Henri, J. F., "Organisational culture and performance measurement systems," Accounting, Organisation and Society, 30, (2006): 77-103.

Holynskyy, Y., "The importance of financial management principles in the State budget execution," Annals of Spiru Haret University - Economics Series, 17 (4), (2017): 1928.

Hopwood, A. G., An accounting system and managerial behaviour (Hampshire, UK: Saxon House, 1973).

Jensen, M., "Paying people to lie: The truth about the budgeting process," European Financial Management, 9(3), (2003): 379-406.

Kaiser, H., “An index of factorial simplicity,” Psychometrika, 39(1), (1974): 31-36. 


\section{Issue 1/2018}

Kenis, I., "Effects of budgetary goal characteristics on managerial attitudes and performance," The Accounting Review (1979): 707-721.

Khin, E., "Comparative study of the budgeting process reforms within two international accounting organisations: Malaysia and Australia perspectives," Journal of Basic and Applied Sciences, 4(9), (2010): 4142-4150.

Kochi, S., Budgetary participation in Malaysian local authorities. Unpublished Ph.D. thesis submitted to Aston University. Retrieved from http://eprints.aston.ac.uk/ 16497/1/Budget\%2Bparticipation\%2Bin\%2BMalaysian\%2Blocal\%2Bauthorites (2012).

Langfield, S. K., Thorne, H. \& Hilton, T. W., Management Accounting (4 ${ }^{\text {th }}$ ed.) (Australia: McGraw-Hill Ltd, 2006).

Leach-Lopez, M. A., Stammer, J. W. \& McNair, F. M., "Differences in the role of job relevant information in the budgetary participation-performance relationship among US and Mexican managers: A question of culture or communication?" Journal of Management. Accounting Research, 1(19), (2007): 105-136.

Little, H. T., Magner, N. \& Welker, RB., "The fairness of formal budgetary procedures and their enactment," Group Organisation Management, 27(2), (2002): 209-225.

Luarn, P. \& Huang, K., "Factors influencing government employee performance via information systems use: An empirical study," Electronic Journal of e-Government, 7(3), (2009): 227-240.

Maiga, S., "Antecedents and consequences of budgetary participation," in Marc J. Epstein, John Y. Lee (ed.), Advances in Management Accounting (Advances in Management Accounting, Volume 14) (Emerald Group Publishing Limited, 2005), p. 211-231.

Maitland, I., Budgeting for non-financial managers: How to master and maintain effective budgets (Englewood Cliffs, NJ: Prentice Hall, 2000).

Malgwi, A. \& Unegbu, A., "Budget in Nigerian public sector: Need for balanced scorecard perspective," International Journal of Finance and Accounting, 1(2), (2012): 1-6.

Mănescu, R., "Budget and development at the beginning of the 21 st century: Let us understand the past in order to design the future," Annals of Spiru Haret University Economics Series, 10(4), (2010): 103-108

Marginson, D., Ogden, S. \& Frow, N., "Budgeting and innovation: Complements or contradictions?" CIMA Research Report. Retrieved from: http://www.cimaglobal.com/ executivereports, 2006.

Marginson, D. \& Ogden, S., Budgeting and innovation. Retrieved from: $\mathrm{http}: / /$ www.cimaglobal.com/financialmanagement, 2005.

Mia, L., "The impact of participation in budgeting and job difficulty on managerial performance and work motivation: A research note," Accounting, Organization and Society, 14, (1989): 347-357. 


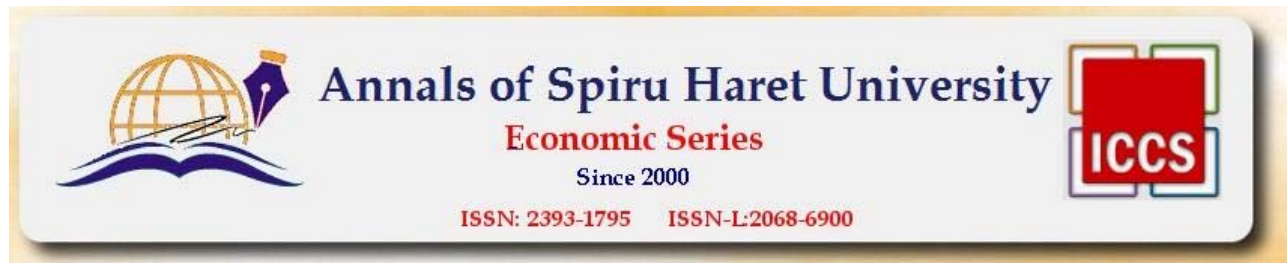

Issue 1/2018

Mihai, I., "Budget for Romania in 2010: Constraints and challenges," Annals of Spiru Haret University - Economics Series, 10(2), (2010): 107-114.

Milani, K., "The relationship of participation in budget-setting to industrial supervisor performance and attitudes: A Field Study," The Accounting Review, 4(1), (1975): 274-284.

Mullins, L. J. \& Christy, G., Management and organisational behaviour (London: Financial Times Publishing International, 2013).

Nikmah, F., "Antecedents of budgetary participation: Enhancing employees' job performance," Jurnal Studi Akuntansi Indonesia, 1(1), (2012): 1-35.

Noor, I. \& Othman, R. Budgetary participation: How it affects performance and commitment. Retrieved from http://visar.csustan.edu/aaba/Othman2012.pdf, 2012.

Nouri, H. \& Parker, R. J., "The relationship between budgetary participation and job performance: The roles of budget adequacy and organizational commitment," Accounting, Organization, and Society, 23(5), (1998): 467-483.

Nunnally, J., Psychometric theory (New York: McGraw-Hill, 1978).

Olaopa, T., A critical overview of public sector reform in Nigeria: Framework of transformation for the Federal Civil Service. Retrieved from http://www.tunjiolaopa.com/a-critical-overview-of-public-sector-reform-in-nigeriaframework-of-transformation-for-the-federal-civil-service/, 2013.

Omolehinwa, E. O. \& Naiyeju, J. K., Government accounting in Nigeria: An IPSAS approach (Lagos: Pumark Nigeria Limited, 2015).

O'Reilly, C., "Corporations, culture, and commitment: motivation and social control in organizations," California Management Review, 31, (1989): 9-25.

Owusu, E., Dwomoh, G., Collins, M., Yaa, G. \& Daniel, O., "Assessing the relationship between budgetary participation and employees' performance of public universities in Ghana: A case of University of Education," International Journal of Academic Research in Accounting, Finance, and Management Sciences, 4(1), (2014): 85-95.

Pilkington, M. \& Crowther, D., Budgeting and control. Retrieved from: http://www.cimaglobal.com/financialmanagement, 2007.

Rasmussen, N., Process improvement for effective budgeting and financial reporting (Hoboken, NJ: Wiley, 2003).

Schiff, M. \& Lewin, A. Y., "The impact of people on budgets," The Accounting Review, 4, (1970): 259-268.

Sheppard, B. H., Hartwick, J. \& Warshaw, P. R., "The theory of reasoned action: A metaanalysis of past research with recommendations for modifications and future research," Journal of Consumer Research, 15, (1988): 325-343.

Shields, J. F. \& Shields, M. D., "Antecedents of participative budgeting," Accounting, Organizations and Society, 1, (1998): 49-76.

Stedry, A., Budget Control and Cost Behavior (Englewood Cliffs, N.J.: Prentice-Hall, 1960). 


\section{Annals of Spiru Haret University \\ Economic Series \\ Since 2000 \\ ISSN: 2393-1795 \\ ISSN-L:2068-6900}

\section{Issue 1/2018}

Stevens, J., Applied Multivariate Statistics for the Social Sciences (4th ed.) (Mahwah, New Jersey: Lawrence Erlbaum Associates, 2002).

Vancouver, J. B., "Living systems theory as a paradigm for organizational behaviour: understanding humans, organizations, and social processes," Behavioural Science, 41(3), (1996): 165-204.

Wentzel, K., "The Influence of fairness perceptions and goal commitment on managers' performance in a budget setting," Behavioral Research in Accounting, 14(1), (2002): 247-271.

Williams, J. J., Macintosh, N. B. \& Moore, J. C., "Budget related behaviour in public sector organization: Some empirical evidence," Accounting, Organisation and Society, 15(3) (1990): 221-246.

Yahya, M. N., Nik, A., Nik N. \& Fatima, A. H., "Budgetary participation and performance: Some Malaysian evidence," International Journal of Public Sector Management, 21, (6), (2008): 658-673

Yuen, D., "Antecedents of budgetary participation: Enhancing employees' job performance," Managerial Auditing Journal, 22(5), (2007): 533-548.

Yukl, G., Leadership in Organizations (Englewood Cliffs, NJ: Prentice Hall, 1994). 
Issue 1/2018

APPENDICES

Appendix 1: Questionnaire Administration

\begin{tabular}{|l|l|l|l|l|l|}
\hline Organisation & $\begin{array}{l}\text { Population } \\
\text { (a) }\end{array}$ & $\begin{array}{l}\text { Sample size / } \\
\text { number of } \\
\text { questionnaire } \\
\text { distributed (b) }\end{array}$ & $\begin{array}{l}\text { Proportion of } \\
\text { sample size in } \\
\text { relation to } \\
\text { population } \\
\text { (b) / (a) } x 100\end{array}$ & $\begin{array}{l}\text { Number of } \\
\text { copies of } \\
\text { questionnaire } \\
\text { returned and } \\
\text { usable (c) }\end{array}$ & $\begin{array}{l}\text { Response } \\
\text { rate } \\
\text { (c) / (b) x } 100\end{array}$ \\
\hline AMCON & 16 & 15 & $93.7 \%$ & 10 & $66.67 \%$ \\
\hline FCC & 25 & 24 & $96.0 \%$ & 20 & $83.33 \%$ \\
\hline FIRS & 238 & 147 & $61.8 \%$ & 89 & $60.54 \%$ \\
\hline NERC & 67 & 57 & $85.1 \%$ & 35 & $61.40 \%$ \\
\hline NIPC & 30 & 28 & $93.3 \%$ & 20 & $71.42 \%$ \\
\hline Total & $\mathbf{3 7 6}$ & $\mathbf{2 7 1}$ & & $\mathbf{1 7 4}$ & $\mathbf{6 4 \%}$ \\
\hline
\end{tabular}

Appendix 2: Reliability Test Results

\begin{tabular}{|l|l|l|}
\hline \multicolumn{1}{|c|}{ Variable } & No. of items & Cronbach's Alpha \\
\hline Budgetary Participation & 6 & 0.727 \\
\hline Managerial Performance (before factor analysis) & 8 & 0.773 \\
\hline Managerial Performance (after factor analysis) & 3 & 0.788 \\
\hline
\end{tabular}

Appendix 3: Test of Normality using One-Sample Kolmogorov Smirnov statistics

\begin{tabular}{|ll|r|r|}
\hline & & \multicolumn{1}{|c|}{$\begin{array}{c}\text { Budgetary } \\
\text { Participation }\end{array}$} & $\begin{array}{c}\text { Managerial } \\
\text { Performance }\end{array}$ \\
\hline $\mathrm{N}$ & & 174 & 174 \\
Normal Parameters & Mean & 6.08 & 6.0326 \\
& Std. Deviation & 0.327 & 0.49359 \\
& Absolute & 0.143 & 0.135 \\
Most Extreme Differences & Positive & 0.086 & 0.130 \\
& Negative & -0.143 & -0.135 \\
Kolmogorov-Smirnov Z & & 1.886 & 1.776 \\
Asymp. Sig. (2-tailed) & & 0.002 & 0.004 \\
\hline
\end{tabular}

a Test distribution is Normal.

${ }^{\mathrm{b}}$ Calculated from data. 
Issue 1/2018

Appendix 4: Kruskal Wallis test of $B P$ and $M P$

Test Statistics ${ }^{\mathrm{a}, \mathrm{b}}$

\begin{tabular}{lrr}
\multicolumn{3}{c}{ Test Statistics $^{\mathrm{a}, \mathrm{b}}$} \\
\hline \hline & $\begin{array}{c}\text { Budgetary } \\
\text { Participation }\end{array}$ & Managerial Performance \\
\hline Chi-Square & 1.207 & 0.681 \\
df & 3 & 3 \\
Asymp. Sig. & 0.751 & 0.878 \\
\hline \hline${ }^{\mathrm{a}}$ Kruskal Wallis Test & \\
${ }^{\mathrm{b}}$ Grouping Variable: Length of time in the company
\end{tabular}

Appendix 5: ANOVA ${ }^{\mathrm{b}}$ Test result for Model 2

\begin{tabular}{llrrrrr}
\hline \hline Model & & Sum of Squares & df & Mean Square & F & Sig. \\
\hline 1 & Regression & 8.035 & 1 & 8.035 & 40.509 & $0.000^{\mathrm{a}}$ \\
& Residual & 34.114 & 172 & 0.198 & & \\
& Total & 42.149 & 173 & & & \\
\hline \hline
\end{tabular}

${ }^{\mathrm{a}}$ Predictors: (Constant), BP

${ }^{\mathrm{b}}$ Dependent Variable: MP

Appendix 6: Results from Exploratory Factor Analysis for Managerial performance 6a: KMO and Bartlett's Test for Managerial Performance)

Kaiser-Meyer-Olkin Measure of Sampling Adequacy.

Bartlett's Test of Sphericity - Approx. Chi-Square

Sig.

0.030 
Issue 1/2018

6b: Total Variance Explained (Managerial Performance)

\begin{tabular}{|c|c|c|c|c|c|c|}
\hline \multirow[b]{2}{*}{ Component } & \multicolumn{3}{|c|}{ Initial Eigen values } & \multicolumn{3}{|c|}{ Rotation Sums of Squared Loadings } \\
\hline & Total & $\begin{array}{c}\text { \% of } \\
\text { Variance }\end{array}$ & $\begin{array}{c}\text { Cumulative } \\
\%\end{array}$ & Total & $\begin{array}{c}\% \text { of } \\
\text { Variance }\end{array}$ & $\begin{array}{c}\text { Cumulative } \\
\%\end{array}$ \\
\hline 1 & 1.477 & 16.409 & 16.409 & 1.355 & 15.053 & 15.053 \\
\hline 2 & 1.286 & 14.290 & 30.699 & 1.295 & 14.393 & 29.446 \\
\hline 3 & 1.168 & 12.979 & 43.678 & 1.210 & 13.439 & 42.886 \\
\hline 4 & 1.063 & 11.816 & 55.494 & 1.135 & 12.609 & 55.494 \\
\hline 5 & 0.982 & 10.906 & 66.401 & & & \\
\hline 6 & 0.920 & 10.219 & 76.620 & & & \\
\hline 7 & 0.749 & 8.321 & 84.941 & & & \\
\hline 8 & 0.727 & 8.075 & 93.015 & & & \\
\hline 9 & 0.629 & 6.985 & 100.000 & & & \\
\hline
\end{tabular}

Extraction Method: Principal Component Analysis.

Appendix 7: Descriptive Statistics on Budgetary Participation and Managerial Performance

\begin{tabular}{|c|c|c|c|c|c|}
\hline & $\mathrm{N}$ & Minimum & Maximum Mean & Std. Deviation & $p$ value* \\
\hline $\begin{array}{l}\text { Budgetary } \\
\text { Participation }\end{array}$ & 174 & 5 & 6.08 & 0.327 & 0.751 \\
\hline $\begin{array}{l}\text { Managerial } \\
\text { Performance }\end{array}$ & 174 & 5 & 6.03 & 0.494 & 0.878 \\
\hline Valid N (listwise) & 174 & & & & \\
\hline
\end{tabular}



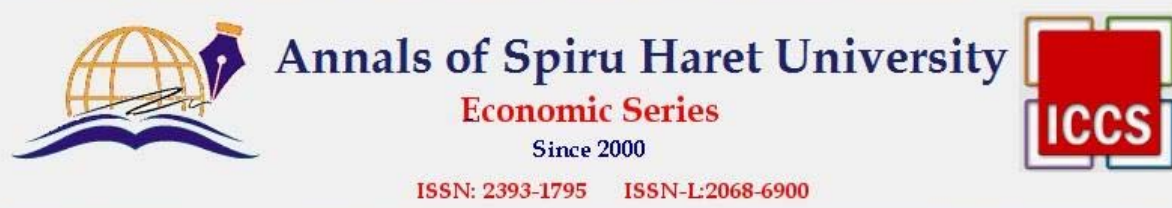

Issue 1/2018

Appendix 8: Interpretation of Correlation Coefficients and Coefficients of Determination adopted for the Study

\begin{tabular}{|l|c|c|l|}
\hline $\begin{array}{c}\text { Interpretation of } \\
\text { correlation coefficient } \\
\text { (strength of } \\
\text { relationship) }\end{array}$ & $\begin{array}{c}\text { Correlation } \\
\text { coefficient }(\boldsymbol{r})\end{array}$ & $\begin{array}{c}\text { Coefficient of } \\
\text { determination (R } \\
\text { square) }\end{array}$ & $\begin{array}{c}\text { Interpretation of } \\
\text { Coefficient of } \\
\text { determination } \\
\text { (impact of IV on DV) }\end{array}$ \\
\hline Perfect relationship & 1.00 & $0.90-1.00$ & Overwhelming \\
\hline Very Strong & $0.70-0.99$ & $0.70-0.89$ & Very Large \\
\hline Strong & $0.50-0.69$ & $0.50-0.69$ & Large \\
\hline Moderate & $0.30-0.49$ & $0.10-0.49$ & Moderate \\
\hline Weak & $0.10-0.29$ & $0.01-0.09$ & Weak \\
\hline No relationship & $<0.10$ & $<0.01$ & No impact \\
\hline
\end{tabular}

Source: Authors' Compilation 